Case Reports

\title{
ACUTE MYELOID LEUKAEMIA OF MIXED MEGAKARYOCYTIC AND ERYTHROID ORIGIN: A CASE REPORT AND REVIEW OF THE LITERATURE
}

\author{
L. Daniëls ${ }^{1}$, K. Guerti' ${ }^{1}$ K. Vermeulen ${ }^{1}$, H. De Raeve ${ }^{2}$, E. Van Assche ${ }^{3}$, AL. Van de Velde ${ }^{4}$, \\ ZN. Berneman ${ }^{4}$, M. Van Der Planken ${ }^{1}$
}

Key words: acute myeloid leukaemia, erythroleukaemia, megakaryoblast, multilineage involvement

\section{ABSTRACT}

We report the case of a 78-year-old man who presented with acute myeloid leukaemia showing subpopulations of cells expressing platelet-associated markers and the presence of a pan-myeloid component, besides glycophorin A-positive cells. Most of the immature cells had a proerythroblastlike morphology and we classified this case as an FAB-M6 variant, as suggested by Bain (1). According to the WHO classification, this leukaemia fulfilled the criteria of 'AML with multilineage dysplasia' (2). Immunophenotyping characteristics showed two distinct aberrant subpopulations, a young pan-

1 Laboratory of Haematology, Antwerp University Hospital, Edegem, Belgium

2 Laboratory of Anatomopathology,

Antwerp University Hospital, Edegem, Belgium

3 Laboratory of Cytogenetics, Antwerp University Hospital, Edegem, Belgium

4 Division of Haematology, Antwerp University Hospital, Edegem, Belgium

Address for Correspondence: Liesbeth Daniëls

Meidoorn 21/1

2640 Mortsel

Tel: +32 (0)486346727

E-mail: danielslies@hotmail.com myeloid (CD45+ with low density, CD34+, CD117+, CD13+, CD33+, partial cytoplasmic myeloperoxidase (MPO)+) population with platelet-associated markers (CD41+, CD42+, CD61+) and a CD45+, CD117+, CD34- population with partial CD235a positivity indicative for erythroid maturation. This case belongs to the group of 'early' erythroblastic leukaemias where a subset of progenitor cells present with erythroid-megakaryocyte bipotentiality or are blocked at an early BFU-E (burst-forming unit erythrocyte)-like stage of erythroid differentiation $(11,12,13)$.

\section{INTRODUCTION}

We report the case of de novo leukaemia showing subpopulations of cells expressing platelet-associated markers and the presence of a pan-myeloid component, besides glycophorin A-positive cells. Recent experimental studies support the hypothesis that during normal haematopoietic development, erythroblasts and megakaryoblasts arise from a common committed progenitor, the BFU E/MK (burst-forming unit erythrocyte megakaryocyte). Consistent with this common origin, erythroid and megakaryocytic gene expression are largely regulated by the same transcriptional regulatory elements, including GATA-1 and NF-E2. Genetic manipulation of either of these transcriptional factors leads to abnormalities in both lineages, supporting this close relationship $(3,4,5,6)$. We reasoned on the base 
of morphologic, immunophenotypic and cytogenetic findings that in this patient a leukaemia had occurred at the progenitor cell level common to both erythroid and megakaryocytic lineages. In the WHO classification, this case is designated as an 'AML with multilineage dysplasia'(2). But this uncommon haematologic malignancy poses difficulties in precise FAB classification (7, $8)$. On the base of morphologic characteristics we concluded an erythroleukaemia FAB M6 variant, as suggested by Bain (1).

By reviewing the literature this case seems to be a very rare haematologic malignancy presenting with heterogenous clinical and laboratory features. The clinical, morphologic, immunophenotypic, and cytogenetic characteristics are reviewed in this article.

\section{RESULTS (Table 1)}

\section{Clinical and laboratory characteristics}

A 78-year-old man was admitted to our hospital presenting with complaints of back pain, fatigue and malaise since a month. At presentation his complete blood count showed a leukocyte count of $16.2 \times 10^{9} / \mathrm{L}$

\begin{tabular}{|c|c|}
\hline Gender & Male \\
\hline Age & 78 years \\
\hline Symptoms & Back pain, fatigue, malaise \\
\hline Leukocyte count $\left(\times 10^{9} / \mathrm{L}\right)$ & $16.2(4.3-10)$ \\
\hline Haematocrit (\%) & $36.0(40-50)$ \\
\hline Haemoglobin (g/dL) & $12.5(13-17)$ \\
\hline Platelet count $\left(\times 10^{9} / \mathrm{L}\right)$ & $40(140-440)$ \\
\hline Blasts (\% in peripheral blood) & 3 \\
\hline Marrow blasts (\%) & $\begin{array}{l}47.3 \text { morphologically } \\
\text { proerythroblast-like cells }\end{array}$ \\
\hline Dysplasia & $\begin{array}{l}\text { Myeloid cells: } 13 \% \text {; Mature } \\
\text { erythroid precursors: } 7.9 \% \text {; Blast } \\
\text { cells: } 47.3 \%\end{array}$ \\
\hline Cytochemistry & $\begin{array}{l}\text { ANAE-; Peroxidase-; PAS+; } \\
\text { sporadic ringed sideroblasts }\end{array}$ \\
\hline $\begin{array}{l}\text { Immunophenotype subpopulation } 1 \\
\text { (29\% of the cellularity) }\end{array}$ & $\begin{array}{l}\text { CD45+ low density, CD34+, } \\
\text { CD117+, CD13+, CD33+, partial } \\
\text { cytoplasmic MPO+, CD11C-, } \\
\text { CD235a-, CD41+, CD42+, CD61+, } \\
\text { CD7+ }\end{array}$ \\
\hline $\begin{array}{l}\text { Immunophenotype subpopulation } 2 \\
\text { ( } 22 \% \text { of the cellularity) }\end{array}$ & $\begin{array}{l}\text { CD45+ low density, CD34-, } \\
\text { CD117+, partial CD235a+ }\end{array}$ \\
\hline Cytogenetics & MAKA \\
\hline Treatment & $\begin{array}{l}\text { Induction chemotherapy } \\
\text { (mitoxantrone, cytarabine, } \\
\text { etoposide) }\end{array}$ \\
\hline Survival (months) & 3 \\
\hline
\end{tabular}

(4.3-10), a haematocrit of $36.0 \%$ (40-50), a haemoglobin of $12.5 \mathrm{~g} / \mathrm{dL}$ (13-17) and a platelet count of 40 $\times 10^{9} / \mathrm{L}$ (140-440). Eight per cent circulating immature cells ( $3 \%$ blasts) were noted on the peripheral blood smear. Biochemical findings were LDH $4949 \mathrm{U} / \mathrm{L}$ (313618), D-dimers $2.4 \mu \mathrm{g} / \mathrm{mL}(0-0.5)$, iron $58 \mu \mathrm{g} / \mathrm{dL}$ (28180), AST $149 \mathrm{U} / \mathrm{L}$ (5-40), ALT $274 \mathrm{U} / \mathrm{L}$ (7-56), AF 212 U/L (36-95), GGT $386 \mathrm{U} / \mathrm{L}$ (13-45) and CRP $3.4 \mathrm{mg} / \mathrm{dL}$ $(<0.5)$.

The diagnosis of AML M6 variant (acute erythroleukaemia) was made based on the bone marrow aspirate findings. Induction chemotherapy consisting of mitoxantrone, cytarabine and etoposide was complicated by cordecompensation, atrial fibrillation and mild acute renal insufficiency. During the period of neutropaenia the patient developed a pneumonic infiltration successfully treated with broad spectrum antibiotics and antifungal agents. Because of good clinical and haematological recovery with normalisation of thrombocyte and leukocyte count in absence of abnormal cells, the patient could leave the hospital after one month.

However, one week later he was hospitalised again with serious back pain, fast atrial fibrillation, fatigue, vertige, confusion and night sweating. Laboratory findings were LDH 1942 U/L, AST $31 \mathrm{U} / \mathrm{L}$, ALT $46 \mathrm{U} / \mathrm{L}, \mathrm{AF}$ $186 \mathrm{U} / \mathrm{L}, \mathrm{GGT} 213 \mathrm{U} / \mathrm{L}, \mathrm{CRP} 8.9 \mathrm{mg} / \mathrm{dL}$, leukocyte count $18.6 \times 10^{9} / \mathrm{L}$, haematocrit $31.4 \%$, haemoglobin 10.6 $\mathrm{g} / \mathrm{dL}$ and a platelet count of $185 \times 10^{\%} / \mathrm{L}$. The diagnosis of progressive leukaemia was made and the patient died within 3 months of diagnosis.

\section{Bone marrow aspirate: Cytological characteristics}

At onset, the bone marrow aspirate showed a granulopoiesis (myeloid component: $33.2 \%$ ) characterised by a mild dysplasia (13\%) with mainly neutrophils $(24.6 \%)$ and a few granulocyte progenitors (myelocytes: $1 \%$, metamyelocytes: $2.6 \%$, neutrophilic bands: $5 \%$ ). A remarkably rich erythroid component (proerythroblasts: $47.3 \%$, basophilic erythroblasts: $5.3 \%$, polychromatophilic erythroblasts: $2.6 \%$ ) mainly consisted of blast cells showing a proerythroblast-like aspect. These erythroid blast cells (Figure 1a) were characterized by an abundant deep basophilic cytoplasm with the exception of a zone localized near the nucleus. They showed typical "blebs" as seen in proerythroblasts. The nucleus was round or slightly irregular in shape with fine chromatine distribution and a few with visible nucleolus. These atypical blasts did not contain azurophilic granules. Moreover, mature erythroid precursors (basophilic 


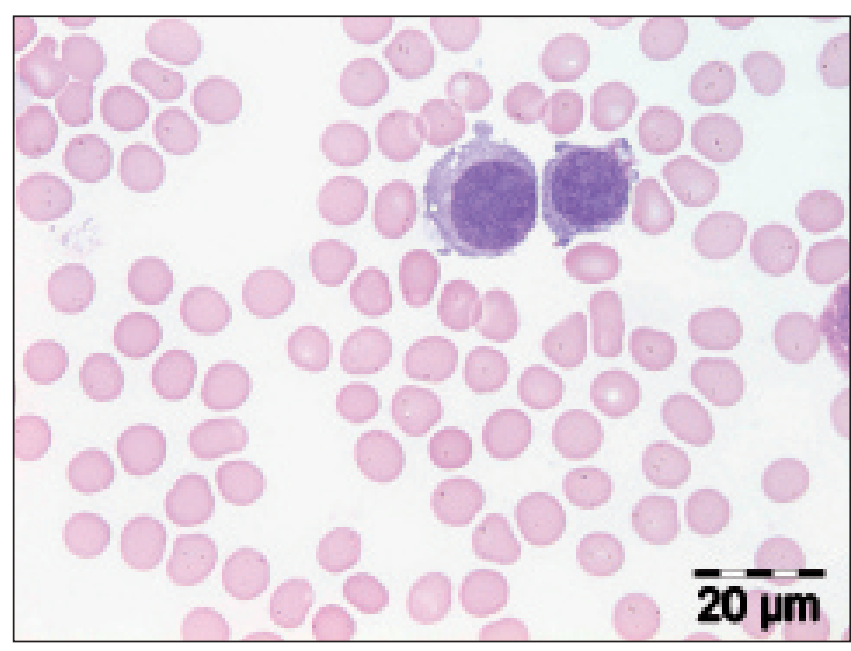

Figure 1a: Bone marrow smear shows two atypical proerythroblasts.

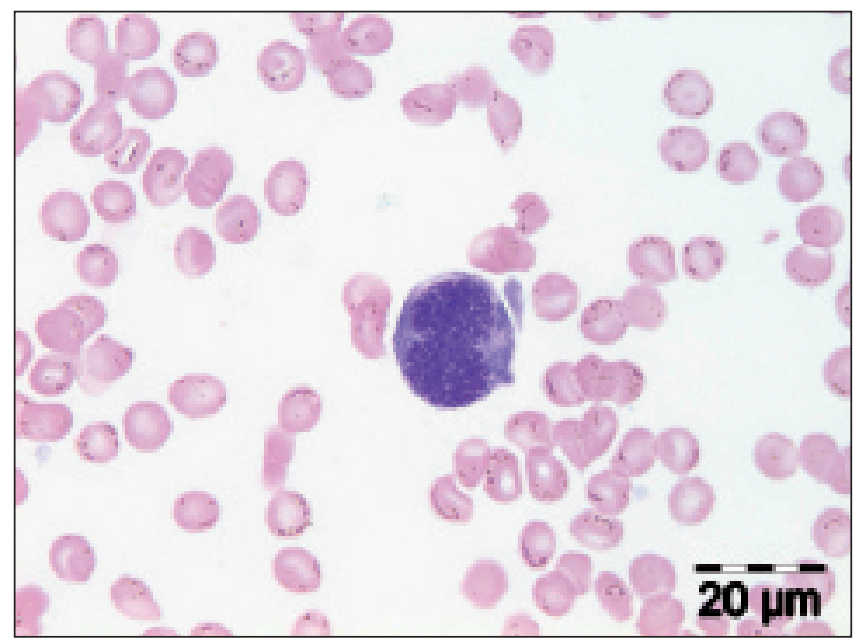

Figure 1b: Bone marrow smear shows a binucleated erythroblast.

to acidophilic erythroblasts) were limited in percentage $(7.9 \%)$ and showed strong dysplasia (Figure 1b). Morphologically no other type of blast could be recognized.

By cytochemical staining these blasts were $\alpha$ naphtyl acetate esterase (ANAE) negative, peroxidase negative and periodic acid-Schiff (PAS) positive (blocklike staining pattern), which confirmed their erythroblast aspect. Sporadically ringed sideroblasts were observed with Perls staining.

In this case, fewer than $30 \%$ (20\% according the WHO classification) of non-erythroid cells were blasts and consequently the FAB criteria for AML M 6 could not be fulfilled; nevertheless this seemed to be the category where it fittest most naturally. Following the suggestion of Bain (1) we designated an AML M6 variant with criteria for diagnosis being that more than $50 \%$ of bone marrow cells are erythroid and more than $30 \%$ are immature erythroid cells resembling proerythroblasts or basophilic erythroblasts (7).

However, the morphological appearance, which showed that most of the immature cells had a proerythroblast-like morphology, was not completely compatible with the immunophenotyping characteristics which we will describe in the next chapter.

\section{Bone marrow aspirate and bone marrow biopsy: Immunophenotyping characteristics}

Mononuclear cells were isolated by density gradient separation, after labelling for 15 minutes with monoclonal antibodies, cells were washed and red blood cells were lysed using ammoniumchloride. Data were acquired on a Cytomics FC500 (Beckman Coulter, Fullerton, CA, USA) and analysed using CXP software. For intracellular immunostaining cells were fixed and permeabilized using IntraStain (DakoCytomation, Glostrup, Denmark).

At onset we found the following immunophenotyping characteristics for the bone marrow aspirate. Immunostaining 1 (CD13/CD33/CD34/CD15/CD45) showed a young (CD34+, CD45+ with low density) population accounting for $29 \%$ of the cellularity and positive for pan-myeloid markers of differentiation (CD13/CD33) (Figure 2a). Immunostaining 2 (CD235a/ CD11c/CD34/CD117/CD45) showed that this CD34+ population was also CD117+, CD11c- and CD235a(Figure 2b). Other markers expressed on this population were the platelet glycoproteins CD41 (73\% within the CD34+ population), CD61 (57\% within the CD34+ population) and CD42 (25\% within the CD34+ population). The CD34+ population also expressed the T-cell marker CD7 (33\% within the CD34+ population) and had cytoplasmic MPO positivity (29\% within the CD34+ population). In addition, by using immunostaining 2 , a population with a different phenotype was revealed. This population, accounting for $22 \%$ of the cellularity, consisted of cells positive for CD45 (low density) and CD117 but negative for CD34. In the dot plot CD45/ CD235a (Figure 2b) there was a continuum of CD117+/ CD34- cells who gradually lost their CD45 positivity and gained CD235a positivity suggesting the erythroid nature of these cells, which is supported by their proerythroblast-like morphology.

In conclusion, two distinct aberrant subpopulations were observed, a young pan-myeloid (CD45+, CD34+, CD117+, CD13+, CD33+, partial cytoplasmic MPO+) 


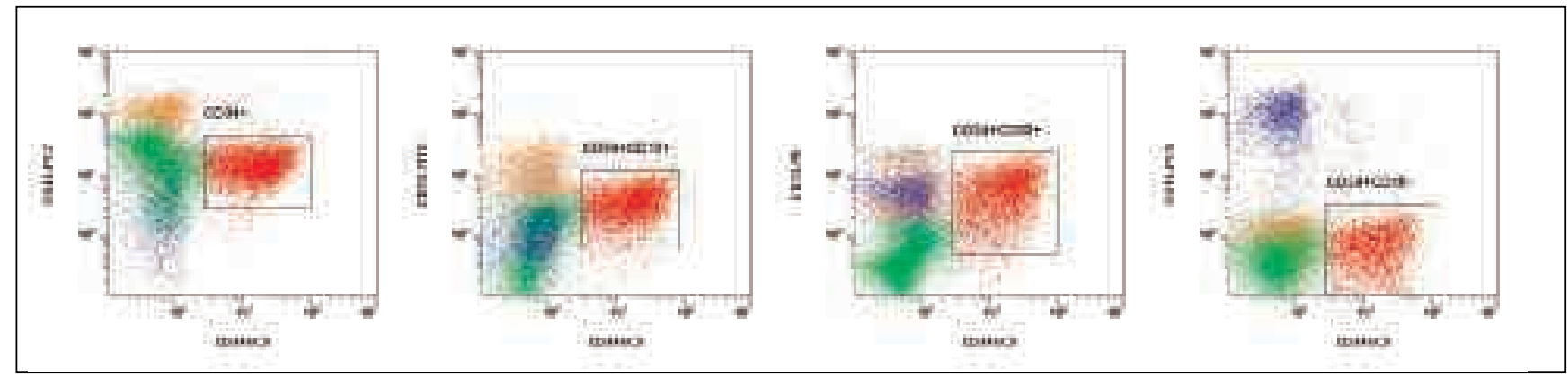

Figure 2a: Immunostaining 1: CD13-FITC/CD33-PE/CD34-ECD/CD15-PE-Cy5/CD45-PE-Cy7. Colour preference: Red: CD34+/CD45+ low density Blue: CD15+/CD13- Orange: CD15-CD13+ Green: CD34-/CD15-/CD33-/CD45+ low density. Gating strategy: ungated
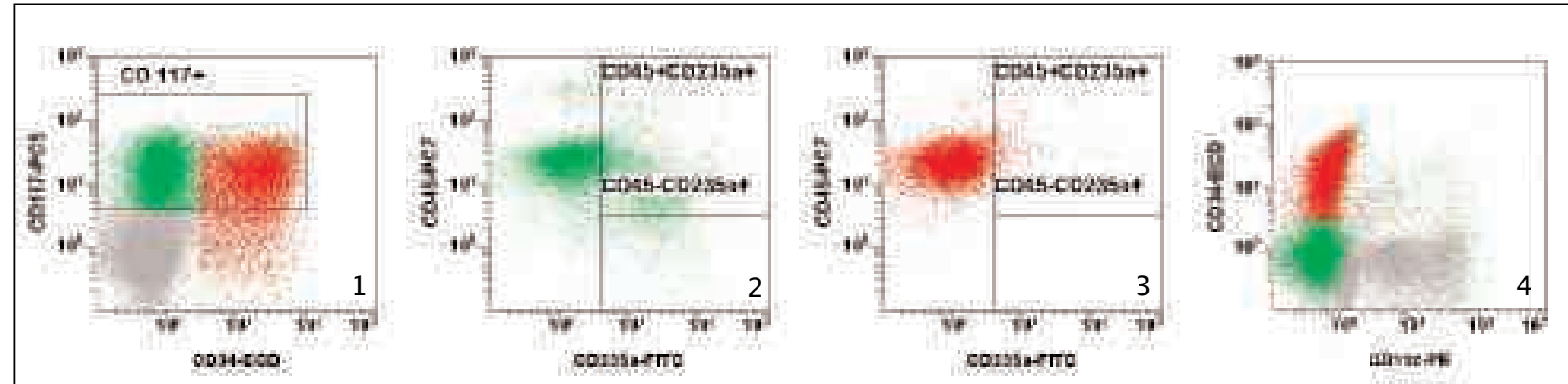

Figure 2b: Immunostaining 2: CD235a-FITC/CD11C-PE/CD34-ECD/CD117-PE-Cy5/CD45-PE-Cy7. Red: CD34+/CD45+ low density Green: CD117+/CD34-/CD45+ low density. Gating strategy: (1) Ungated (2) Gated on CD117+/CD34- (3) Gated on CD117+/CD34+ (4) Ungated

population with platelet-associated markers (CD41+, CD42+, CD61+) and a CD45+, CD117+, CD34-population with partial CD235a positivity indicative for erythroid maturation.

The megakaryocytic differentiation of the first subpopulation was also confirmed by immunohistochemical analysis applied to a fixed, paraffine-embedded bone marrow biopsy. Fifty-seven per cent of all the blasts were positive for factor VIII (Figure 3).

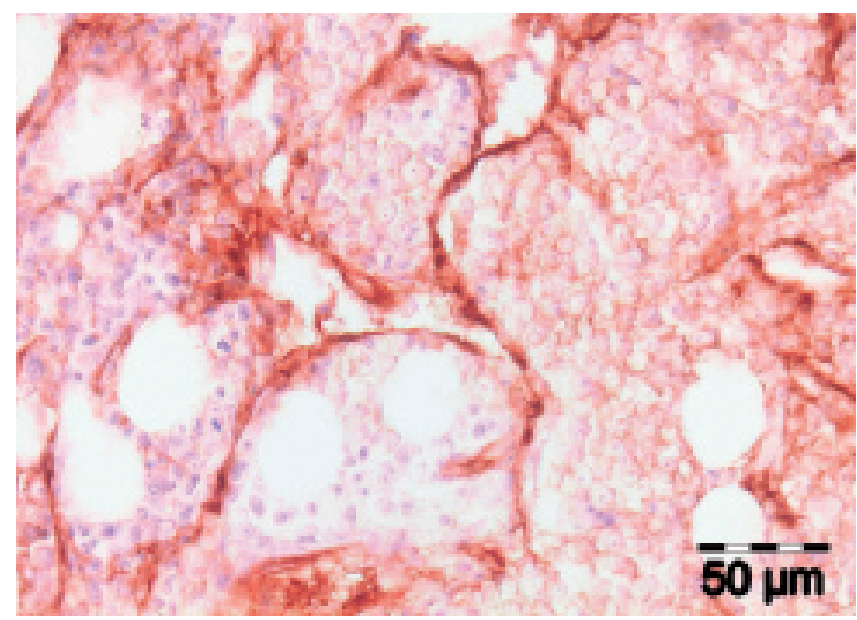

Figure 3: Immunohistochemical stain of blasts on bone marrow biopsy with antibody to factor VIII.

\section{Bone marrow aspirate: Cytogenetics}

Cytogenetic analyses (Figure 4) were performed on bone marrow cells cultured in Amniomax (Gibco Invitrogen) for 24 to 48 hours. After harvesting the unstimulated cultures, metaphase spreads were made and G-banding was performed. An attempt was made to analyse at least 20 metaphases, and at least 10 karyotypes were prepared. Karyotypes were designated according to the International System for Human Cytogenetic Nomenclature (2005).

In total, 28 metaphases were found on the cytogenetic preparations. A normal chromosome complement was found in 10 metaphases. In the other 18 metaphases the morphology and the resolution of the banding pattern were subnormal. As a result, karyotyping was hampered. Most of the metaphases showed an at random loss of different chromosomes. A common feature in all the metaphases was the presence of 2 marker chromosomes (= structurally abnormal chromosome in which no part can be identified) and the loss of chromosome 5 . In order to identify those marker chromosomes, the fluorescence in situ hybridisation (FISH) technique was applied on the G-banded slide, since this were the only fixed cells available. Unfortu- 


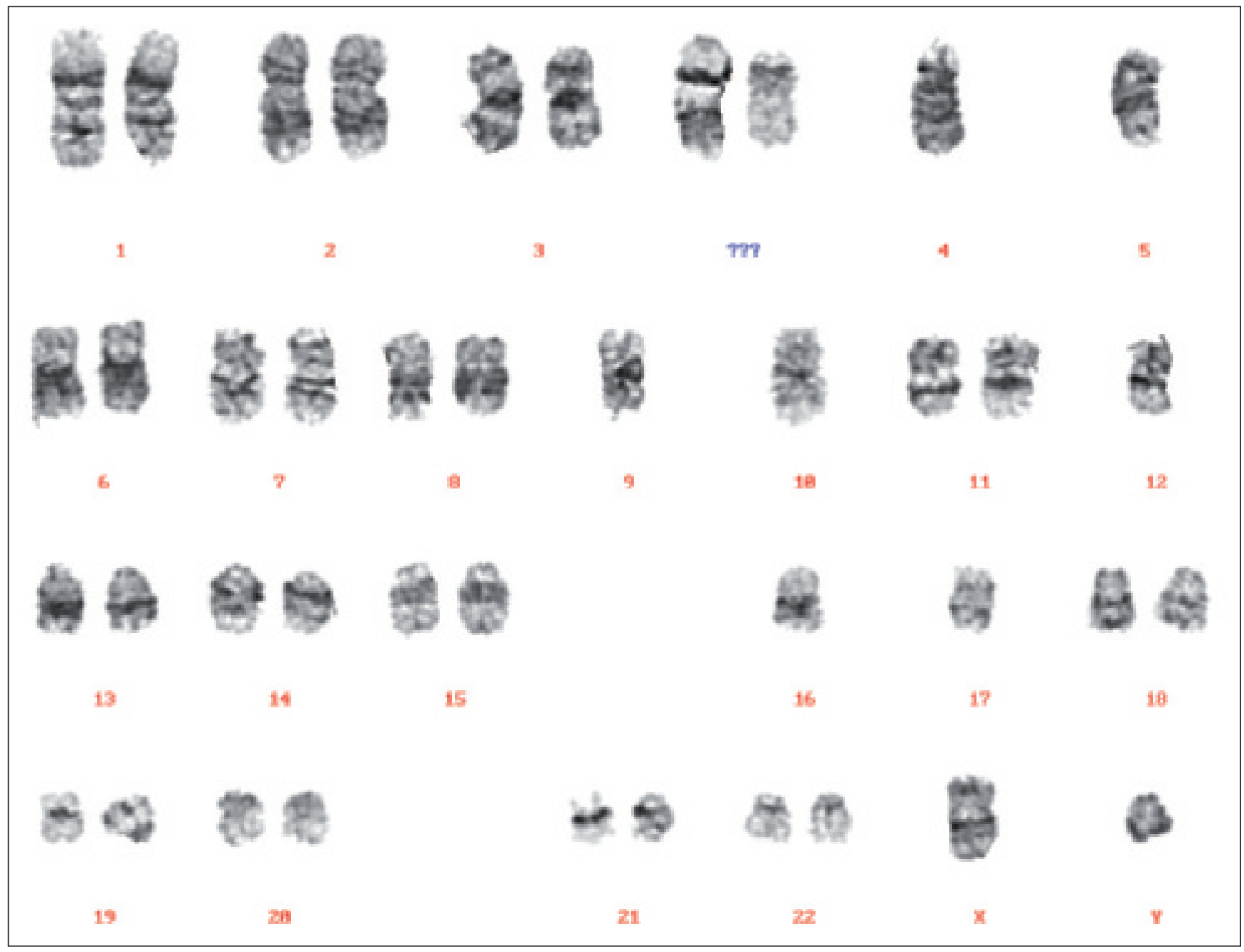

Figure 4: Karyotype of abnormal clone

nately, the abnormal metaphases did not show analysable FISH signals. No further characterisation of the marker chromosomes was thus possible. Since chromosome 5 always deletes all the abnormal metaphases, it can be assumed that parts of this chromosome are indeed present in at least 1 of the rearranged marker chromosomes. The cytogenetic abnormalities could be classified as complex (major karyotype aberrations, MAKA) since they showed $\geq 3$ abnormalities $(7,10$, 11).

\section{DISCUSSION}

Erythroleukaemia (AML M6) seems to be the category in which our case fits most naturally, because the bone marrow morphologically almost exclusively consists of erythroid cells including many very primitive erythroid cells (47.3\% proerythroblast-like cells). Following the suggestion of Bain (1) we designated an AML M6 variant with criteria for diagnosis being more than $50 \%$ of bone marrow cells are erythroid and more than $30 \%$ are immature erythroid cells resembling proerythroblasts or basophilic erythroblasts (7).

The diagnosis of AML M6, particularly when the cells have a very immature phenotype, may be difficult to distinguish from other types of AML, particularly megakaryoblastic (9), and also from ALL or lymphoma. In our case there was a lack of expression of lymphoid antigens what excluded the latter diagnosis. Distinction from megakaryoblastic leukaemia was more difficult because of the concurrent erythroid-megakaryocytic involvement. The immunophenotyping characteristics revealed 2 distinct aberrant subpopulations, a young pan-myeloid (CD45+, CD34+, CD117+, CD13+, CD33+, partial cytoplasmic MPO+) population (29\% of the 
cellularity) with platelet-associated markers (CD41+, CD42+, CD61+) and a CD45+, CD117+, CD34- population (22\% of the cellularity) with partial CD235a positivity indicative for erythroid maturation. The cytochemical profile (PAS+, ANAE-, peroxidase-) confirmed the erythroblast and megakaryoblast involvement, but could not confirm the partial cytoplasmic MPO positivity found with flow cytometry. Following the WHO this case satisfied the criteria for multilineage involvement (2). In conclusion, the case should be classified as AML with multilineage dysplasia, because there is dysplasia involving $\geq 50 \%$ of the cells of at least 2 lines. The myeloid component is characterized by a mild dysplasia (13\%). Mature erythroid precursors all showed strong dysplasia (7,9\%). Together with the atypical blasts $(47,3 \%)$, dysplasia is present in $68,2 \%$ of the cells. Demonstrated by flow cytometry, some of these blasts showed megakaryocytic involvement, what was also proven by factor VIII positivity. Morphologically no other megakaryocytic forms were found in the bone marrow aspirate.

A review of the literature shows that leukaemias of erythroid lineage represent infrequent haematologic malignancies presenting with heterogenous clinical and laboratory features. 'Early' erythroblastic leukaemias, like our case, where a subset of progenitor cells present with erythroid-megakaryocyte bipotentiality or are blocked at an early BFU-E (burst-forming unit erythrocyte)-like stage of erythroid differentiation and not morphologically identifiable by the usual criteria, are very uncommon diseases. They may arise as de novo $A M L$, in Down's syndrome, as therapy-related AML or as blast crisis in $\operatorname{CML}(11,12,13)$.

In the literature (Table 2) we found 11 paediatric cases of 'early' erythroblast leukaemia, whereas 2 de novo leukaemias associated with MAKA (10), 5 cases

Table 2: Review of the literature

\begin{tabular}{ll}
\hline $\begin{array}{l}\text { Cases 'early' erythroblast } \\
\text { leukaemia }\end{array}$ & Cytogenetics \\
\hline 2 paediatric cases $(10)$ & $\begin{array}{l}\text { De novo leukaemias associated with } \\
\text { MAKA }\end{array}$ \\
5 paediatric cases $(13,14)$ & Trisomy 21 \\
3 paediatric cases $(13,15)$ & $\begin{array}{l}\text { Isolated chromosomal } \\
\text { abnormality appearance }(t(1 ; 22) ; \\
\text { inv }(6)(p 22 ; q 22) ; \text { del }(5 q)) \\
\text { Congenital case without } \\
\text { chromosomal abnormality } \\
1 \text { paediatric case }(5)\end{array}$ \\
10 adult cases $(11,12,13,16)$ & $\begin{array}{l}\text { De novo leukaemias associated with } \\
\text { MAKA }\end{array}$
\end{tabular}

associated with trisomy $21(13,14), 3$ cases with isolated chromosomal abnormality appearance (1 case with $t(1 ; 22), 1$ with inv(6)(p22;q22) and 1 with del(5q)) $(13,15)$ and one congenital case without chromosomal abnormality (5). We found 10 adult cases of de novo 'early' erythroblast leukaemias, all associated with MAKA $(11,12,13,16)$ and, as in our case, associated with a short median survival. Although MAKA were observed in all these de novo 'early' erythroblast leukaemias, complex karyotypes have also been found in other MDS and AML, possibly reflecting exposure to myelotoxic agents (11).

The reason for the low incidence of erythroleukaemia could be due to the fact that glycophorin A detected by monoclonal antibodies (McAbs) is not a sufficiently early marker of erythroid differentiation (12). This molecule is considered to be a very specific but rather late erythroid marker (13). Indeed, Glycophorin A detected by these McAbs is not expressed on the membrane of erythroid progenitors, i.e., CFU-E (colony-forming unit erythrocyte) and BFU-E (burst-forming unit erythrocyte). Although not specific, CD71 (the transferrin receptor) is present on the earliest recognizable erythroid cells and its reactivity is suggestive of erythroid differentiation since it is rarely present in other myeloid leukaemias (10). Another not specific marker is the CD36 marker, which usually detects erythroid progenitors at earlier stages of differentiation and is characteristically positive in acute megakaryoblastic leukaemias. Other McAbs that recognize antigens and that are expressed before GPA during normal erythropoiesis are anti-carbonic anhydrase I (CAI) and FA6-152 McAbs (12). Unfortunately we did not apply these markers in one of our immunostainings, which could maybe prove the erythroid involvement of the CD34+ cells and the partial erythroid maturation from these CD34+ cells.

\section{CONCLUSION}

This case is an example of acute myeloid leukaemia of mixed megakaryocytic and erythroid origin. We were confronted with the difficulties in classifying this leukaemia with multilineage involvement. According to the morphologic characteristics this case was classified as an FAB M6 variant, as suggested by Bain (1). In the WHO classification, cases of AML assigned to FAB M6 category fall into various categories. Most are designated 'AML with multilineage dysplasia' and 'acute erythroid leukaemia' (1). Our case fulfilled the first designation. 


\begin{abstract}
We beschrijven de casus van een 78 -jarige man die zich presenteerde met een acute myeloide leukemie gekenmerkt door subpopulaties van cellen met expressie van plaatjes geassocieerde en pan-myeloide markers, naast glycophorine A-positieve cellen. Meeste van deze immature cellen hadden een proerythroblasten morfologie en we klasseerden deze casus als een FAB-M6 variant, voorgesteld door Bain (1). Volgens de WHO klassificatie, voldoet deze leukemie aan de criteria van 'AML met multilineage dysplasia' (2). Immunofenotypering toont twee distinct aberrante subpopulaties, een jonge pan-myeloide (CD45+ met lage densiteit, CD34+, CD117+, CD13+, CD33+, partiële cytoplasmatische myeloperoxidase (MPO)+) populatie met plaatjes geassocieerde markers (CD41+, CD42+, CD61+) en een CD45+, CD117+, CD34- populatie met partiële CD235a positiviteit indicatief voor erythroide maturatie. Deze casus behoort tot de groep van 'vroege' erythroblast leukemieën waarbij een subset van progenitor cellen een erythroid-megakaryocytaire bipotentialiteit vertonen of geblokkeerd zijn bij een vroege BFU-E (burstforming unit erythrocyte) stadium van erythroide differentiatie $(11,12,13)$.
\end{abstract}

\section{REFERENCES}

1. Bain BJ, Clark DM, Lampert IA, Wilkins BS. Bone marrow pathology. 154-5, Oxford, Blackwell Science, 2001.

2. Jaffe ES, Harris NL, Stein H, Vardiman JW. World Health Organization: Classification of Tumours Pathology \& Genetics: Tumours of Haematopoietic and Lymphoid Tissues. 97-9, Lyon, IARC Press, 2001.

3. Goldfarb NA, Wong D, Racke FK. Induction of megakaryocytic differentiation in primary human erythroblasts: a physiological basis for leukemic lineage plasticity. Am J Pathol 2001; 158(4): 1191-8.
4. Komatsu N, Kirito K, Izumi T, Eguchi M, Miura Y. GATA-1 and erythropoietin receptor genes are highly expressed in erytrholeukemia. Exp Hematol 1998; 26(12): 1148-54.

5. Mori T, Kaneko H, Kumagai MA, et al. Congenital leukaemia with a mixed phenotype of megakaryoblasts and erythroblasts: a case report and characterization of the blasts. Br J Haematol 1997; 96(4): 740-2.

6. Kubota TA, Okamura S, Shimoda K, Ikematsu W, Otsuka T, Niho Y. Analysis of c-kit expression of human erythroleukemia cell line, HEL: clonal variation and relationship with erythroid and megakaryocytic phenotype. Leukemia Research 1995; 19(4): 283-90.

7. Goldberg SL, Noel P, Klumpp TR, Dewald GW. The erythroid leukemias: A comparative study of erythroleukemia (FAB M6) and Di Guglielmo Disease. Am J Clin Oncol 1998; 21(1): 42-7.

8. Davey FR, Abraham N Jr, Brunetto VL, et al. Morphologic characteristics of erythroleukemia (acute myeloid leukemie; FABM6): a CALGB study. Am J Hematol 1995; 49(1): 29-38.

9. Pombo de Oliveira MS, Gregory C, Matutes E, Parreira A, Catovsky D. Cytochemical profile of megakaryoblastic leukaemia: a study with cytochemical methods, monoclonal antibodies, and ultrastructural cytochemistry. J Clin Pathol 1987; 40: 663-9.

10. Day DS, Gay JN, Kraus JS, et al. Erythroleukemia of childhood and infancy: a report of two cases. Ann Clin Lab Sci 1997; 27(2): 142-50.

11. Cuneo A, Van Orshoven A, Michaux JL, et al. Morphologic and cytogenetic studies in erythroleukemia: evidence for multilineage involvement and identification of two distinct cytogeneticclinicopathological types. Br J Haematol 1990; 75(3): 346-54.

12. Villeval JL, Cramer P, Lemoine F, et al. Phenotype of early erythroblastic leukemias. Blood 1986; 68(5): 1167-74.

13. Garand R, Duchayne E, Blanchard D, et al. Minimally differentiated erythroleukemia (AML M6 'variant'): a rare subset of AML distinct from AML M6. Br J Haematol 1995; 90(4): 868-75.

14. Debili N, Kieffer N, Mitjavila MT, et al. Expression of platelet glycoproteins by erythroid blasts in four cases of trisomy 21 . Leukemia 1989; 3(9): 669-78.

15. Oshima M, Fukushima T, Koike K, Hoshida C, Izumi I, Tsuchida M. Infant leukaemia with $t(1 ; 22)$ presenting proliferation of erythroid and megakaryocytic cell lineages. Rinsho Ketsueki 1999; 40(3): 230-5.

16. Ohata M, Sugiura K, Otsuka S, Nonaka K, Nakazawa M. Acute erythroblastic leukaemia presenting as FAB M6 with surface marker positive for megakaryocytic and erythroid: report of a case. Rinsho Ketsueki 1994; 35(2): 127-34. 


\title{
Auguentin Retolact
}

\section{bij bacteriële luchtweginfecties}

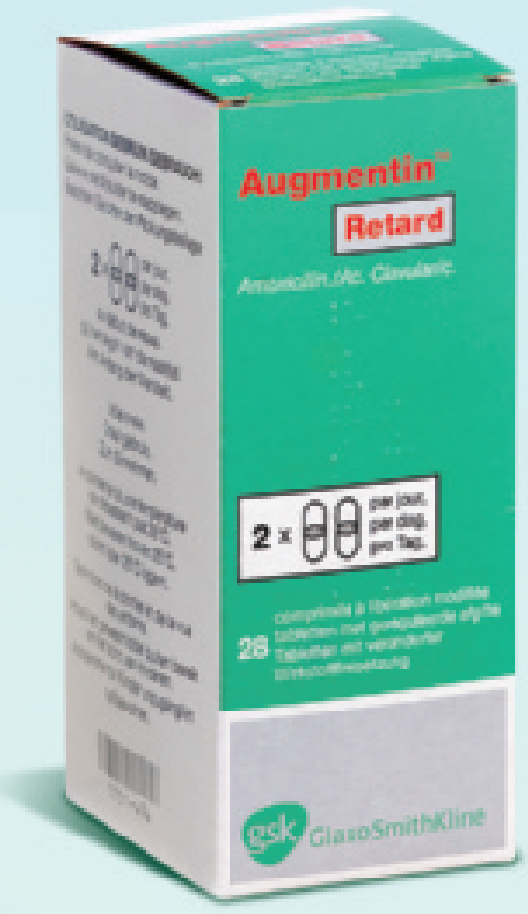

28 tabletten voor 7 behandelingsdagen
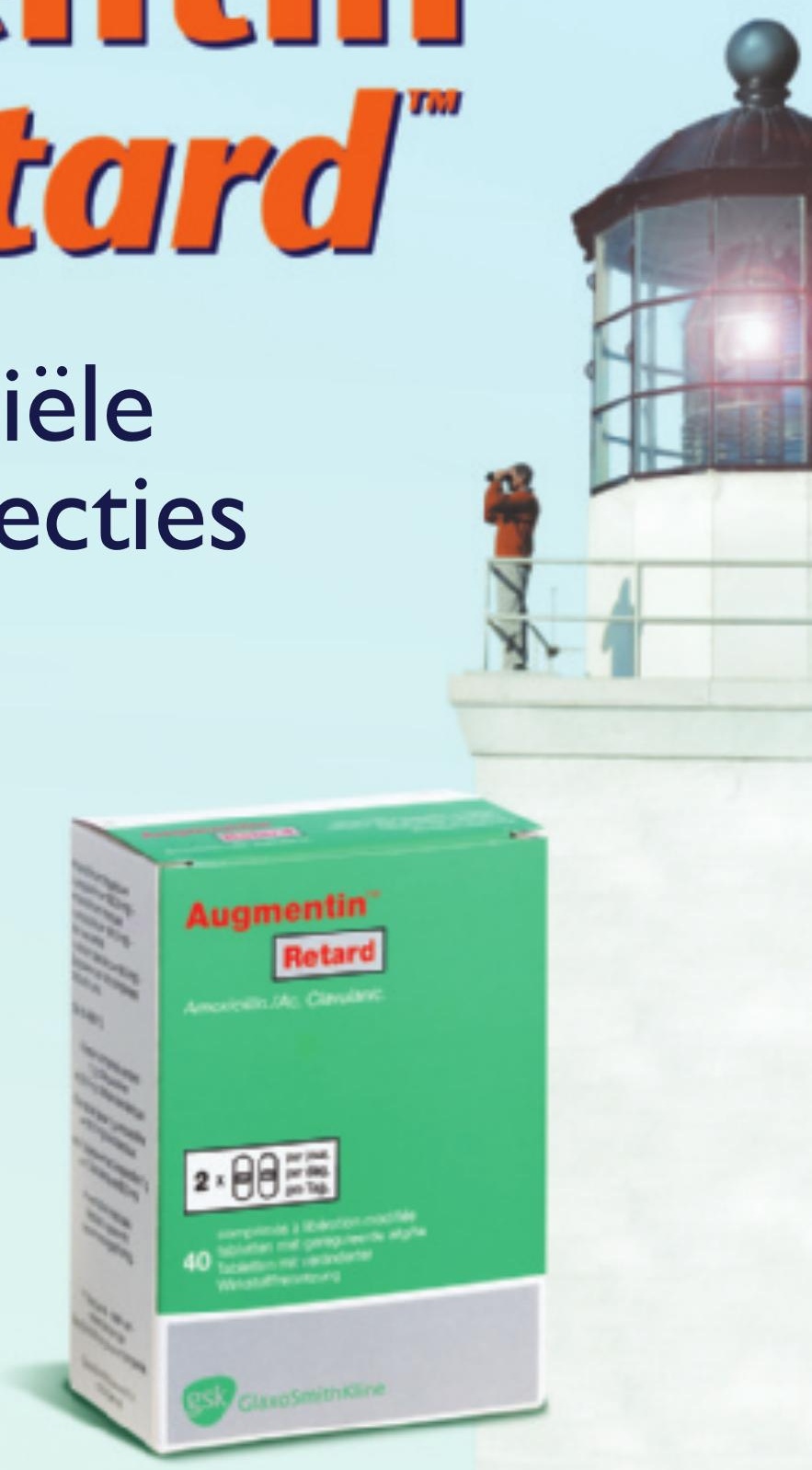

\section{0 tabletten voor \\ 10 behandelingsdagen}

\section{$2 \times 2$ tabletten / dag}

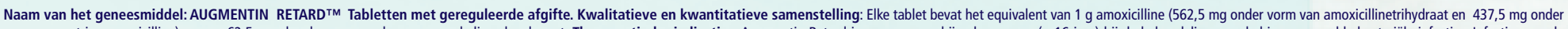

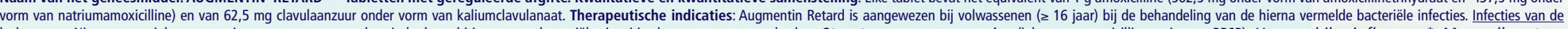

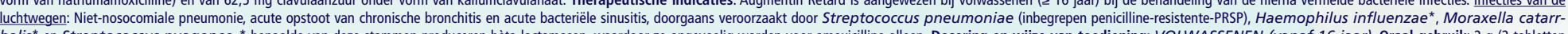

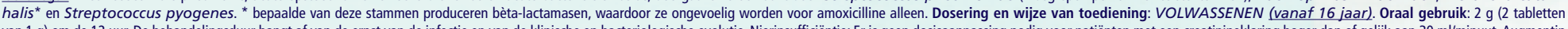

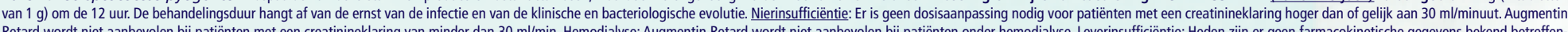

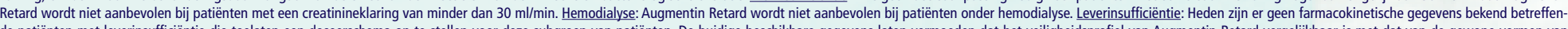

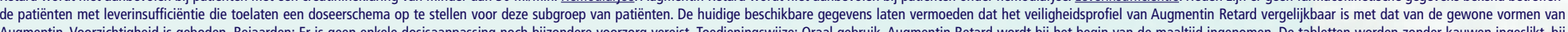

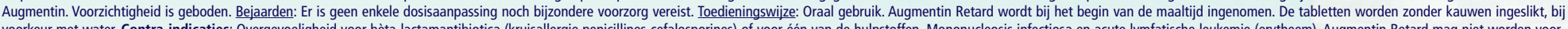

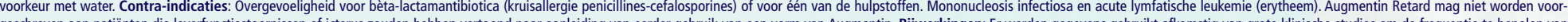

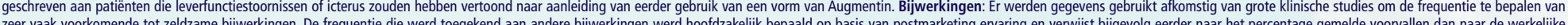

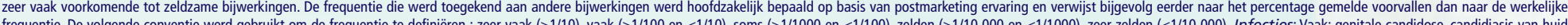
(

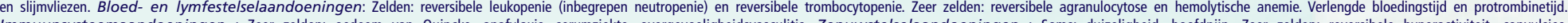

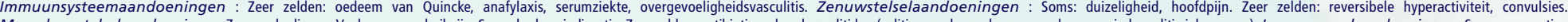

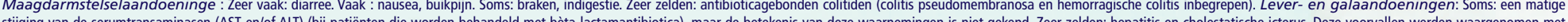

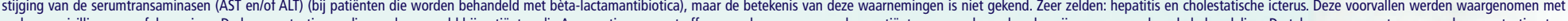

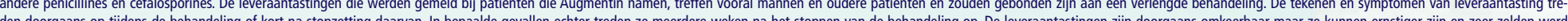

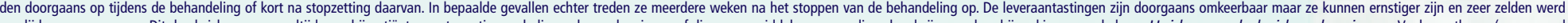

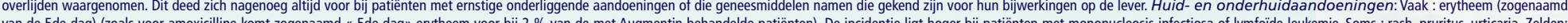

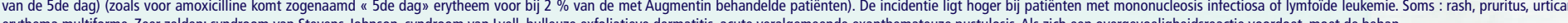
erythema muliore. Zeer zelden: syndroom van Stevens-Johnson, syndroom van Lyell, bulleuze exfoliatieve dermatitis, acute veralgemeende exanthemateuze pustulosis. Als zich een overgevoeligheidsreactie voordoet, moet de behandeling gestopt van de laatste de




\section{$70 \%$}

réduction du risque" de fractures vertébrales' risque" de fractures de la hanche'
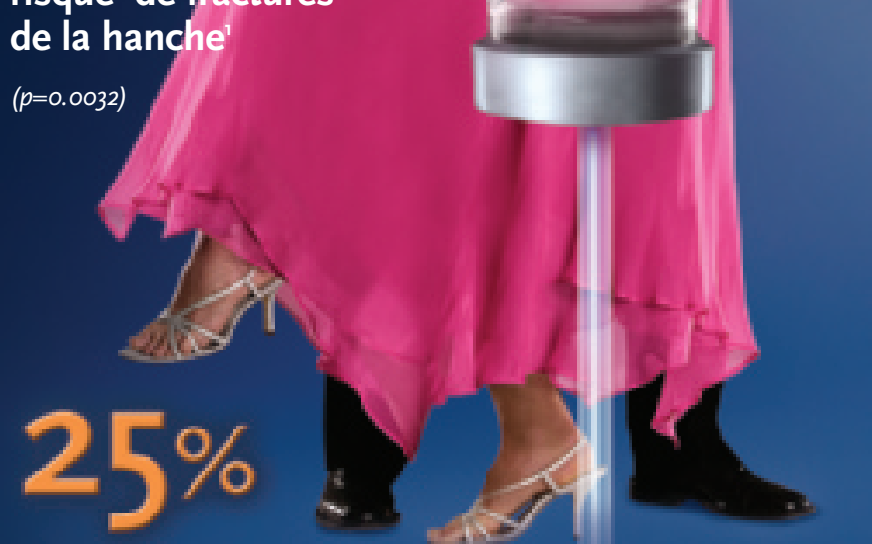

réduction du risque" de fractures non vertébrales"

$(p<0.001)$

Dénomination : Aclasta $5 \mathrm{mg}$ solution pour perfusion Composition et forme : Chaque flacon de $100 \mathrm{ml}$ de solution contient $5 \mathrm{mg}$ d'acide zolédronique anhydre, correspondant à $5,330 \mathrm{mg}$ d'acide zolédronique monohydraté. Un ml de solution contient $0,05 \mathrm{mg}$ d'acide zolédronique anhydre correspondant à $0,0533 \mathrm{mg}$ d'acide zolédronique monohydraté. Indications : Traitement de l'ostéoporose post-ménopausique chez les patientes à risque élevé de fractures. Traitement de la maladie de Paget. Posologie : Pour le traitement de l'ostéoporose post-ménopausique, la dose recommandée est une perfusion intraveineuse de $5 \mathrm{mg}$ d'Aclasta, administrée une fois par an. Pour la maladie de Paget, Aclasta doit uniquement être prescrit par des médecins expérimentés dans le traitement de cette pathologie. La dose recommandée est une unique perfusion intraveineuse de $5 \mathrm{mg}$ d'Aclasta. Répétition du traitement de la maladie de Paget : aucune donnée spécifique n'est disponible concernant un traitement répété. Il a été observé une période de rémission prolongée chez les patients répondeurs au traitement de la maladie de Paget après une unique administration d'Aclasta. Aclasta $(5 \mathrm{mg} / 100 \mathrm{ml}$, solution pour perfusion prête à l'emploi) est administré par l'intermédiaire d'un dispositif de perfusion, avec prise d'air et à vitesse de perfusion constante. La durée de la perfusion ne doit pas être inférieure à 15 minutes. Les patients doivent être correctement hydratés avant l'administration d'Aclasta. Cela est particulièrement important pour les patients âgés et les patients qui reçoivent un traitement diurétique. Un apport adapté en calcium et vitamine D est recommandé simultanément à l'administration d'Aclasta. De plus, chez les patients atteints de la maladie de Paget, il est fortement conseillé d'administrer une supplémentation adaptée en calcium correspondant à un apport en calciumélément d'au moins $500 \mathrm{mg}$ deux fois par jour, pendant au moins les 10 jours suivant l'administration d'Aclasta. L'incidence des effets indésirables survenant dans les trois premiers jours suivant l'administration d'Aclasta peut être diminuée en administrant du paracétamol ou de l'buprofène après l'administration d'Aclasta. Patients insuffisants rénaux : L'utilisation d'Aclasta n'est pas recommandée chez les patients dont la clairance de la créatinine est < $40 \mathrm{ml} / \mathrm{min}$ en raison d'une expérience clinique limitée dans cette population. Aucun ajustement de la dose n'est nécessaire chez les patients dont la clairance de la créatinine est $\geq 40 \mathrm{~m} / \mathrm{min}$. Patients insuffisants hépatiques : Aucun ajustement de la dose n'est nécessaire. Patients âgés $\& 65$ ans) : Aucun ajustement de la dose n'est nécessaire puisque la biodisponibilité, la distribution et l'élimination ont été similaires chez les patients âgés et chez les patients plus jeunes. Enfants et adolescents : Aclasta ne doit pas être utilisé chez l'enfant en dessous de 18 ans compte tenu de l'absence de données concernant la sécurité et l'efficacité. Contre-indications : Hypersensibilité à la substance active ou à l'un des Ache

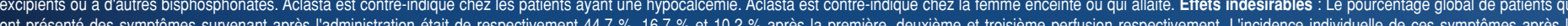
: premiere admistration : majorité de ces symptômes est survenu dans les trois premiers jours suivant l'administration d'Aclasta, a été d'intensité légère à modérée et a disparu dans les trois jours suivant leur survenue. L'incidence des symptômes survenant dans les trois premiers jours suivant l'administration d'Aclasta peut être diminuée en administrant du paracétamol ou de l'buprofène peu après l'administration d'Aclasta. L'incidence globale des fibrillations auriculaires était de $2,5 \%$ (96 des 3 862 ) et de $1,9 \%$ ( 75 des 3852 ) chez les patients recevant respectivement Aclasta et le placebo. Le taux de fibrillations auriculaires classé comme évènements indésirables graves était de 1,3\% (51 sur 3862 ) chez les patientes traitées par Aclasta comparé à $0,6 \%$ (22 sur 3852 ) chez les patientes recevant le placebo. Le mécanisme de l'augmentation de cette incidence des fibrillations auriculaires n'est pas connu. Les effets indésirables très fréquents ( $\geq 1 / 10)$, fréquents $(\geq 1 / 100,<1 / 10)$, peu fréquents $(\geq 1 / 1000,<1 / 100)$ et rares $(\geq 1 / 10000,<1 / 1000)$ sont présentés dans le Tableau 1. Au sein de chaque fréquence de groupe, les effets indésirables sont présentés suivant un ordre décroissant de gravité.

\begin{tabular}{|c|c|c|}
\hline Affections cardiaques & Fréquent & Fibrillation auriculaire \\
\hline Affections du système nerveux & $\begin{array}{l}\text { Fréquent } \\
\text { Peu fréquent }\end{array}$ & $\begin{array}{l}\text { Céphalées, vertiges } \\
\text { Léthargie, paresthésies, somnolence, tremblements, syncope, } \\
\text { dysgueusie }\end{array}$ \\
\hline Affections oculaires & $\begin{array}{l}\text { Peu fréquent } \\
\text { Rare }\end{array}$ & $\begin{array}{l}\text { Conjonctivite, douleur oculaire, uvéite } \\
\text { Episclérite, iritis }\end{array}$ \\
\hline Affections de l'oreille et du labyrinthe & Peufréquent & Vertiges \\
\hline Affections gastro-intestinales & $\begin{array}{l}\text { Fréquent } \\
\text { Peu fréquent }\end{array}$ & $\begin{array}{l}\text { Naussées, vomissements, diarrhée } \\
\text { Dyspepsie, douleur abdominale, sécheresse buccale, oesophagite }\end{array}$ \\
\hline Affections du rein et des voies urinaires & Peu fréquent & Augmentation de la créatinémie \\
\hline Affiections de la peau et du tissu sous-cutané & Peu fréquent & Eruption cutanée \\
\hline Affections musculo-squelettiques et systémiques & $\begin{array}{l}\text { Fréquent } \\
\text { Peu fréquent }\end{array}$ & $\begin{array}{l}\text { Myalgies, arthralgies, douleurs osseuses, douleurs rachidiennes, } \\
\text { douleurs au niveau des extrémités } \\
\text { GGontlement articulaire, douleurs de l'épaule, spasmes musculaires, } \\
\text { faiblesse musculare, raideur articulaire }\end{array}$ \\
\hline Troubles du métabolisme et de la nutrition & $\begin{array}{l}\text { Fréquent } \\
\text { Peu fréquent }\end{array}$ & $\begin{array}{l}\text { Hypocalcémiet } \\
\text { Anorexie }\end{array}$ \\
\hline $\begin{array}{l}\text { Troubles généraux et anomalies au site } \\
\text { d'administration }\end{array}$ & $\begin{array}{l}\text { Très fréquent } \\
\text { Fréquent } \\
\text { Peu fréquent }\end{array}$ & $\begin{array}{l}\text { Fièvre } \\
\text { Syndrome pseudo-grippal, frissons, fatigue, asthénie, douleurs, } \\
\text { malaise, rigiditét } \\
\text { CEdème périphérique, soif }\end{array}$ \\
\hline Affections psychiatriques & Peu fréquent & Insomnie \\
\hline
\end{tabular}
Effets de classe : Anomalie de la fonction rénale : L'acide zolédronique a été associé à une anomalie de la fonction rénale se manifestant sous forme d'une détérioration de la fonction rénale (c.-̀̀-d. augmentation de la créatininémie) et dans de rares cas insuffisance rénale aiguë. Une insuffisance rénale a été observée après l'administration d'acide zolédronique, en particulier chez les patients présentant une altération rénale préexistante ou des facteurs de risque supplémentaires (par exemple, chimiothérapie anticancéreuse, médicaments néphrotoxiques concomitants, déshydratation sévère, etc.). La majorité de ces patients ont recu une dose de $4 \mathrm{mg}$ toutes les 3 à 4 semaines, mais une anomalie de la fonction rénale a également été observée chez les patients ayant reçu une seule administration. Au cours d'une vaste étude clinique, les modifications de la clairance de la créatinine (mesurée chaque année avan l'injection) et lincidence de l'insuffisance rénale étaient comparables dans les deux groupes de traitement (Aclasta et placebo) sur une période de trois ans. Une augmentation transitoire de la créatininémie a été observée sur 10 jours chez $1,8 \%$ des patientes traitées par Aclasta versus $0,8 \%$ des patientes traitées par le placebo. Hypocalcémie: Lors d'une vaste étude clinique, environ $0,2 \%$ des patientes ont présenté une diminution notable de la calcémie (moins de $1,87 \mathrm{mmo} / /$ ), suite à l'administration d'Aclasta. Aucun cas d'hypocalcémie symptomatique n'a été observé. Au cours d'études menées chez des patients atteints de la maladie de Paget une hypocalcémie symptomatique a été observée chez environ $1 \%$ des patients. Chez tous les patients, l'hypocalcémie a été résolutive. D'aprés l'évaluation des paramètres biologiques issue d'une vaste étude clinique, il a été observé des valeurs, transitoires et asymptomatiques parametres biologiques issue d'une vaste etude clinique, il a ete observe des valeurs, transitoires et asymptomatiques, de calcémie inférieures aux valeurs normales de référence chez $2,3 \%$ des patients traités avec Aclasta comparé a
$21 \%$ des patients traités avec Aclasta dans les études de la maladie de Paget. La fréquence dhypocalcémie était beaucoup moins élevée avec les perfusions suivantes. Tant dans l'étude menée sur l'ostéoporose post-ménopausique que dans les études de la maladie de Paget, tous les patients ont reçu une supplémentation en vitamine D et en calcium. Réactions locales: Au cours d'une vaste étude, des réactions locales au site de perfusion, telles qu'une rougeur, un gonflement et/ou une douleur $(0,7 \%)$, ont été observées après l'administration d'acide zolédronique.

t Fréauent en cas de maladie de Paget uniquement. Pour lhypocalcémie voir ci-dessous. Ostéonécrose de la mâchoire: Des cas d'ostéonécrose (principalement de la mâchoire) ont été peu fréquemment rapportes, principalement chez des patients atteints d'un cancer et traites par bisphosphonates, dont l'acide zoledronique. de la mâchoire présente de multiples facteurs de risque bien documentés incluant le diagnostic d'un cancer, les traitements associés (par exemple : chimiothérapie, radiothérapie, corticothérapie) et des affections associées (par exemple: anémie, troubles de la coalution infection, maladie bucale préexistante). Bien que la causalité ne puisse être établie, il est prudent d'éviter une chirurgie dentaire dont la guérison pourrait être retardée. Au cours d'une vaste étude clinique réalisée chez 7736 patientes, une ostéonécrose de la mâchoire a été observée chez une patiente traitée par Aclasta et chez une patiente traitée par le placebo. Dans les deux cas, lévolution a été favorable. Titulaire et numéro d'enregistrement : Novartis Europharm Limited, Wimblehurst Road, Horsham, West Sussex, H12 5AB, Royaume-Uni. EU/1/05/308/001. Délivrance : Prescription médicale. Dernière mise à jour de la notice : 3.10 .2007 